\title{
Effect of Essential Oil and Organic Acid on Performance, Gut Health, Bacterial Count and Serological Parameters in Broiler
}

Original Article

\section{Euthor(s)}

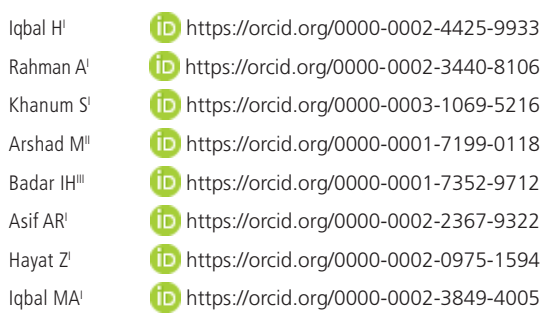

Department of Animal Sciences, University of Veterinary and Animal Sciences, Lahore-Pakistan.

Department of Basic Sciences, University of Veterinary and Animal Sciences, Lahore-Pakistan.

III Department of Meat Sciences, University of Veterinary and Animal Sciences, Lahore-Pakistan.

\section{-Mail Address}

Corresponding author e-mail address Abdur Rahman

Department of Animal Sciences, University of Veterinary and Animal Sciences, Lahore, (Jhang Campus) Pakistan, Jhang, Punjab, 35200, Pakistan.

Phone: 00923464607300

Email: abdurrehman@uvas.edu.pk

\section{- Keywords}

Alternative additives, Intestinal morphology, Organic acids, Serum biochemistry, Total viable count.

\section{ABSTRACT}

A total of 1500 day old broiler chicks were grouped into five treatments; each treatment group further consisted of six replicates. Group A was given a control diet having antibiotics. Group B and C were offered essential oil blend at the proportion of $0.1 \mathrm{~g} / \mathrm{kg}$ and organic acid at the dose rate of $1 \mathrm{~g} / \mathrm{kg}$. Group D was given both essential oil 0.1 $\mathrm{g} / \mathrm{kg}$ and organic acid $1 \mathrm{~g} / \mathrm{kg}$ in combination. Group E was offered only a basal diet without antibiotics and considered as a negative control. The trial lasted for 35 days. Results indicated that the body weight gain and feed conversion ratio (FCR) exhibited significant improvement but insignificant in the case of feed consumption. Bodyweight and FCR were better in group $B$, followed by $C$. Carcass characteristics like eviscerated weight and giblet weight were also improved in group $B$ while dressed weight showed insignificant results. Total cholesterol and high-density lipoproteins (HDL) were unaffected by the treatments; however, increased blood glucose levels and decreased low-density lipoproteins (LDL) concentration were significantly noticed. Treatment groups have no effect on antibody titer against ND at the end of the trial. In gut morphology, significantly higher villus height was observed in group C, but villus width and crypt depth remained unaffected. In conclusion, essential oil and organic acids have improved performance, carcass parameters, serum biochemistry, gut health, and decreased bacterial count.

\section{INTRODUCTION}

The poultry sector is a progressing and well-flourishing business in the world. The poultry industry's present status is the result of improvement in genetics through selection and advances in poultry nutrition, especially through feed formulation. Feed additives are an essential part of feed formulation to increase performance, growth, and production. Proper use of feed additives in feed can improve feed conversion and production (Khan \& lqbal 2016).

For decades, the poultry industry has been using antibiotic feed additives to boost the birds' growth and production. A non-therapeutic dose of antibiotics being used as growth promoters has side effects of developing anti-microbial resistance in the birds (Robinson et al., 2019). This resistance is restricted to microbe and its progeny and transmitted to other irrelevant microbial species through the transfer of special genes. These resistant bacteria are then transferred to human beings and birds via the environment. Additionally, antibiotics residues in animal products seem to be a potential factor of drug resistance in humans. Hence anti-microbial resistance has become a global issue (Agyare et al., 2018). Owing to this anti-microbial resistance, the European Union officially prohibited the utilization of antibiotics for 
Iqbal H, Rahman A, Khanum S, Arshad M, Badar IH, Asif AR, Hayat Z, Iqbal MA

\section{Effect of Essential Oil and Organic Acid on Performance, Gut Health, Bacterial Count and Serological Parameters in Broiler}

improving birds' growth (Abudabos et al., 2017). So, nutritionists' quest becomes more intensified to find efficient alternates of antibiotics to prevent human beings from such harmful effects of antibiotics (Chand et al., 2014).

Various natural substitutes of antibiotics growth promoters have been found efficacious with different mechanisms of action, including enzymes (exogenous or recombinant), prebiotics, clay minerals, probiotics, phytobiotic, nucleotides, symbiotic, antibodies of egg yolk, polyunsaturated fatty acids, and organic acids. All these additives help improve the production and gastrointestinal health of the birds (Sethiya 2016). Herbs and their additives are safe for animals, humans using animal products, and the environment. Herbs or herbal extract positively affect the broiler's performance, immune system, and hematological characteristics. Due to these positive effects and zero safety issues, herbs and their derivatives are good replacers of antibiotics (Hassan et al., 2015). Essential oils can be defined as volatile oils derived from different plants and have anti-microbial, antiviral, antifungal properties, immunomodulatory action, hypolipidemic effect, digestive stimulation effect and have a property to alleviate the heat stress (Gopi et al., 2014). These essential oils are recently being used in poultry feed because the digestion process is also improved and the increase in performance. This may occur due to the positive modulation of gastrointestinal microbiota of the birds (Wade et al., 2018).

Essential oils from Capsicum and cinnamaldehyde causes certain modifications in the expression of genetic material. Capsicum oleoresin caused the changes in the genes which are involved in the metabolism and immunity of birds. Moreover, Cinnamaldehyde also changed genes' expression in inflammatory conditions, antigen presentation, and immune response of humoral origin (O'Bryan et al., 2015). Furthermore, increased thigh muscle percentage and less abdominal fat are the meat characteristics that are also improved by feeding essential oils to broilers (Mehdi et al., 2018).

Organic acids are another alternative that scientists have attracted because of their antibacterial effect against different pathogenic microorganisms. Moreover, it affects decreasing $\mathrm{pH}$ in the gastrointestinal tract, which leads to the improvement of the utilization of nutrients in the broiler birds (Kim et al., 2015). Organic acids are safer feed additive, and the European Union has permitted to use of them in poultry feed (Elnaggar \& EL-Maaty 2017; Sultan et al., 2015). Moreover, organic acids can increase the digestibility of protein, increase the pancreas' secretion, improve gut morphology, and decrease gut microbes' (anti-microbial property) activity (Liu et al., 2017). Phytogenic feed additives, as well as organic acids, are together given in the diet have the capability of enhancing nutrient digestion resulting in increased broiler performance. So, the utilization of both of these compounds can be a better substitute for antibiotic growth promoters (Yang et al., 2018). The interlinked phenomena behind both of these compounds' synergism may be the positive modulation of gastrointestinal microflora. The hydrophobic nature of essential oils makes the bacterial cell membrane more permeable, resulting in an increased influx of organic acids into the cellular cytoplasm. Hence, the organic acids in their un-dissociated form make cellular $\mathrm{pH}$ more acidic, resulting in hampered bacteria's cellular metabolism (Stefanello et al., 2020). The public concerns about the availability of antibiotic residues free meat has a significant role in the consumption of poultry products. Both essential oils and organic acids can provide this antibiotic residue-free meat and will positively contribute to the development of meat industry. Keeping in view all the above facts, this study was designed to evaluate the efficacy of essential oil or organic acids as effective substitutes of antibiotics by investigating their effects on performance, gut health, total bacterial count in intestine and biochemical effects.

\section{MATERIALS AND METHODS}

A total of 1500 broiler (Ross 308) chicks were obtained from a commercial hatchery (Jadeed Group), and they were divided into 5 groups randomly. Each treatment had 300 chicks. Each group was further consisted of 6 replicates having 50 birds in each. Group A was given a normal diet having antibiotics (Enramycine; Enradin 8\% MSD; 0.3 grams/Kg). Group B was given a basal diet and a commercially available essential oils product named Activo ${ }^{\mathrm{TM}}$ (EW Nutrition Germany; Marketed by Ghazi brothers in Pakistan) at the dose rate of 0.1 grams $/ \mathrm{Kg}$ of basal diet. Activo ${ }^{\mathrm{TM}}$ is a blend of essential oils containing oregano, rosemary, cinnamon, and chili pepper extract as active ingredients. Group $C$ consisted of organic acid (Sodium diformate, Formi NDF; Addcon Germany; Marketed by Ghazi brothers in Pakistan) at the dose rate of $1 \mathrm{~g} / \mathrm{Kg}$ of the basal diet. Sodium diformate was composed of formic acid $40 \%$, formate $40 \%$, and sodium $20 \%$. Group D was offered with the mixture of both essential oils and organic acid at the dose rate of $0.1 \mathrm{gram} / \mathrm{Kg}$ of "Activo ${ }^{\mathrm{TM}}$ " essential oils and 
$1 \mathrm{~g} / \mathrm{Kg}$ of organic acid in the diet. Group E contained only a basal diet considering it as a negative control. The whole experimental layout is given in the table 1. The birds were kept in a controlled environment containing pan feeders for feed and nipple drinkers for water availability. Pellet feed and fresh drinking water were given ad libitum. The shed's temperature was maintained at $32^{\circ} \mathrm{C}$ for the early five days then gradually declined according to standard management protocols up to $25^{\circ} \mathrm{C}$. The humidity of the shed was

Table 1 - Experimental design of the study.

\begin{tabular}{|c|c|c|c|c|c|c|}
\hline Diet group & Treatment & Dose rate & $\begin{array}{c}\text { Number of } \\
\text { birds }\end{array}$ & Replicates & $\begin{array}{l}\text { Number of birds } \\
\text { per replicate }\end{array}$ & \multirow{6}{*}{$\begin{array}{l}\text { Total groups: } 5 \\
\text { Replicate/group: } 6 \\
\text { Birds/replicate: } 50 \\
\text { Total birds: } 50 \times 6 \times 5 \\
=1500\end{array}$} \\
\hline A & $\begin{array}{l}\text { Basal diet (Formulated } \\
\text { according to standards) with } \\
\text { antibiotics } \\
\text { (Positive control) }\end{array}$ & As recommended & 300 & 6 & 50 & \\
\hline B & $\begin{array}{l}\begin{array}{l}\text { Activo }^{\mathrm{TM}} \text { Essential oil (EO) } \\
\text { product in basal diet }\end{array} \\
\end{array}$ & \begin{tabular}{|l|l}
100 grams $/$ ton in basal diet or \\
$0.1 \mathrm{gram} / \mathrm{kg}$
\end{tabular} & 300 & 6 & 50 & \\
\hline C & $\begin{array}{l}\begin{array}{l}\text { Organic acid (OA) in basal } \\
\text { diet }\end{array} \\
\end{array}$ & \begin{tabular}{|l|l|}
$\begin{array}{l}\mathrm{kg} / \text { ton or } 1 \mathrm{gram} / \mathrm{kg} \text { in basal } \\
\text { diet }\end{array}$ \\
\end{tabular} & 300 & 6 & 50 & \\
\hline $\mathrm{D}$ & $\begin{array}{l}\text { Organic acid + essential oils } \\
\text { in basal diet }\end{array}$ & $\begin{array}{l}100 \mathrm{~g} / \text { ton of Activo }{ }^{\text {TM }} \text { and } 1 \\
\mathrm{~kg} / \text { ton of organic acids in basal } \\
\text { diet }\end{array}$ & 300 & 6 & 50 & \\
\hline$E$ & $\begin{array}{l}\text { Only basal diet without } \\
\text { antibiotics } \\
\text { (Negative control) }\end{array}$ & As recommended & 300 & 6 & 50 & \\
\hline
\end{tabular}

A: Basal diet supplemented with antibiotics; B: EO $0.1 \mathrm{gram} / \mathrm{kg}$ in basal diet; C: OA $1 \mathrm{gram} / \mathrm{kg}$ in basal diet; D: EO 0.1 gram $/ \mathrm{kg}$ in basal diet and OA 1 gram $/ \mathrm{kg}$ in basal diet; E: Only basal diet (negative control).

kept $(65 \pm 5 \%)$. The lighting period was almost 23 hours per day. The bedding material was rice husk $(8 \mathrm{~cm}$ thickness), and floor space was $5.5 \times 3.5 \times 2 \mathrm{ft}(\mathrm{L} \times \mathrm{W} \times \mathrm{H})$ according to the standard requirement of the chicks. Birds were already vaccinated for Marek's disease by the hatchery. According to standard procedures, the vaccine for Newcastle disease, infectious bronchitis, and infectious bursal disease was given. The whole flock was kept under serious observation until 35 days to complete. All other management procedures were performed according to the recommended protocols. Feed was offered in two phases, starter (0-22 days) and finisher (22-35 days) only. The ingredient and nutrient composition of the formulated diet is given in Table 2. The growth performance of the birds was measured weekly. Feed intake was measured by subtracting refused feed from the total offered feed on weekly basis. Weekly weight gain was measured by subtracting initial body weight from the final body weight. Moreover, the weekly feed conversion ratio was calculated as feed consumed in grams divided by body weight in grams. Carcass parameters such as dressed weight, eviscerated weight, and giblet weight were studied at the trial period's termination. Four birds from each replicate were picked randomly and slaughtered. After slaughtering and removing blood, feathers, and visceral organs, the carcass was weighed to check the dressed weight. Eviscerated weight and giblet weight were recorded. For gut morphology, tissue samples from jejunum were taken from three birds per replicate. The Jejunum was cut about $3 \mathrm{~cm}$ at its central region. Then these samples were preserved in the neutral buffer formalin (SJQW03140 Sigma-Aldrich, Merck; 10\%) for 48 hours. After that, tissue samples were washed by using tap water and then treated with an alcohol solution (L850107 BDH). After sectioning of the tissues, samples were embedded in paraffin with the help of cassettes. Then sample tissue was cut down into 4-micrometer sections via microtome, mounted on the slide, and appropriately stained with $\mathrm{HE}$ (hematoxylin and eosin) stain (Medilines modified H 0706; E 920-921); after that, a light microscope was used for the examination of tissue sections and to determine the villus height and crypts depth. The measurement from the apex (tip of the upper border) of the villus till lamina propria was taken and recorded as villus height. Crypts depth was examined as the length between the crypts and villi according to the recommended protocol (Panda et al., 2009). At the study trial's termination, the day after 35th, blood samples were taken during the birds slaughtering in non-heparinized tubes. Then centrifugation was done at 3000 RPM for 15 minutes for serum separation and kept in the freezer at $-20^{\circ} \mathrm{C}$ until use. Then serum was thawed at room temperature. Serum sample was analyzed to determine total cholesterol, HDL and LDL by the method as described by Kamal \& Ragaa (2014) and Vinus et al. (2017) and glucose concentration was determined by the method as described by Adil et al. (2010). Humoral immunity was estimated by 
Table 2 - Ingredient composition of starter and finisher phase diets.

\begin{tabular}{|c|c|c|c|c|c|}
\hline Ingredients (\%) & Diet group A & Diet group B & Diet group C & Diet group D & Diet group $\mathrm{E}$ \\
\hline \multicolumn{6}{|l|}{ Starter Phase Diet } \\
\hline MCP* & 0.3 & 0.3 & 0.3 & 0.3 & 0.3 \\
\hline Lysine HCL & 0.31 & 0.31 & 0.31 & 0.31 & 0.31 \\
\hline DLM & 0.263 & 0.263 & 0.263 & 0.263 & 0.263 \\
\hline Threonine & 0.1 & 0.1 & 0.1 & 0.1 & 0.1 \\
\hline Salt & 0.22 & 0.22 & 0.22 & 0.22 & 0.22 \\
\hline Soda & 0.1 & 0.1 & 0.1 & 0.1 & 0.1 \\
\hline Betaine $\mathrm{HCL}$ & 0.075 & 0.075 & 0.075 & 0.075 & 0.075 \\
\hline Phytase & 0.01 & 0.01 & 0.01 & 0.01 & 0.01 \\
\hline Coxiril ${ }^{* *}$ & 0.01 & 0 & 0 & 0 & 0 \\
\hline Enramycin & 0.03 & 0 & 0 & 0 & 0 \\
\hline Vitamin premix & 0.055 & 0.055 & 0.055 & 0.055 & 0.055 \\
\hline Mineral premix & 0.055 & 0.055 & 0.055 & 0.055 & 0.055 \\
\hline Trial product & 0 & 0.01 & 0.1 & 0.11 & 0 \\
\hline Rice polish & 0.272 & 0.302 & 0.212 & 0.202 & 0.312 \\
\hline Limestone & 1 & 1 & 1 & 1 & 1 \\
\hline Maize & 53.8 & 53.8 & 53.8 & 53.8 & 53.8 \\
\hline Soyabean Meal & 28 & 28 & 28 & 28 & 28 \\
\hline Canola meal & 4.4 & 4.4 & 4.4 & 4.4 & 4.4 \\
\hline Poultry by-product meal & 3 & 3 & 3 & 3 & 3 \\
\hline Rice Polish & 8 & 8 & 8 & 8 & 8 \\
\hline \multicolumn{6}{|l|}{ Finisher Phase Diet } \\
\hline $\mathrm{MCP}$ & 0.2 & 0.2 & 0.2 & 0.2 & 0.2 \\
\hline Lysine $\mathrm{HCL}$ & 0.333 & 0.333 & 0.333 & 0.333 & 0.333 \\
\hline DL-Methionine & 0.224 & 0.224 & 0.224 & 0.224 & 0.224 \\
\hline Threonine & 0.09 & 0.09 & 0.09 & 0.09 & 0.09 \\
\hline Salt & 0.22 & 0.22 & 0.22 & 0.22 & 0.22 \\
\hline Soda & 0.1 & 0.1 & 0.1 & 0.1 & 0.1 \\
\hline Betaine $\mathrm{HCL}$ & 0.05 & 0.05 & 0.05 & 0.05 & 0.05 \\
\hline Phytase & 0.01 & 0.01 & 0.01 & 0.01 & 0.01 \\
\hline Coxiril & 0.01 & 0 & 0 & 0 & 0 \\
\hline Enramycin & 0.03 & 0 & 0 & 0 & 0 \\
\hline Vitamin Premix & 0.055 & 0.055 & 0.055 & 0.055 & 0.055 \\
\hline Mineral Premix & 0.055 & 0.055 & 0.055 & 0.055 & 0.055 \\
\hline Trial product & 0 & 0.01 & 0.1 & 0.11 & 0 \\
\hline Rice polish & 0.2 & 0.3 & 0.2 & 0.2 & 0.3 \\
\hline Limestone & 0.8 & 0.8 & 0.8 & 0.8 & 0.8 \\
\hline Maize & 63 & 63 & 63 & 63 & 63 \\
\hline Soybean Meal & 25 & 25 & 25 & 25 & 25 \\
\hline Rapeseed meal & 5 & 5 & 5 & 5 & 5 \\
\hline Poultry by-product meal & 3 & 3 & 3 & 3 & 3 \\
\hline Corn gluten $60 \%$ & 1.6 & 1.6 & 1.6 & 1.6 & 1.6 \\
\hline \multicolumn{6}{|c|}{ Nutrient Composition of experimental diets } \\
\hline Ingredients & \multicolumn{2}{|c|}{ Starter } & \multicolumn{3}{|c|}{ Finisher } \\
\hline Moisture (\%) & \multicolumn{2}{|c|}{11.5} & \multicolumn{3}{|c|}{11.5} \\
\hline $\mathrm{CP}(\%)$ & \multicolumn{2}{|c|}{23} & \multicolumn{3}{|c|}{21} \\
\hline Ash (\%) & \multicolumn{2}{|c|}{5} & \multicolumn{3}{|c|}{4} \\
\hline Crude Fat (\%) & \multicolumn{2}{|c|}{4} & \multicolumn{3}{|c|}{4.5} \\
\hline Crude Fiber (\%) & \multicolumn{2}{|c|}{3} & \multicolumn{3}{|c|}{4} \\
\hline Metabolizable Energy (Kcal/Kg) & \multicolumn{2}{|c|}{2900} & \multicolumn{3}{|c|}{2950} \\
\hline
\end{tabular}

${ }^{*} \mathrm{MCP}=$ Mono-calcium phosphate ${ }^{*}$ Coxiril $(\mathrm{B}=$ Coccidiostat containing $0.5 \%$ Diclazuril as active ingredient; $\mathrm{A}:$ Basal diet supplemented with antibiotics; B: EO 0.1 $\mathrm{gram} / \mathrm{kg}$ in basal diet; C: OA $1 \mathrm{gram} / \mathrm{kg}$ in basal diet; D: EO 0.1 gram $/ \mathrm{kg}$ in basal diet and OA $1 \mathrm{gram} / \mathrm{kg}$ in basal diet; E: Only basal diet (negative control) 
using antibody titer of IgG against the NDV vaccine by standard hemagglutination inhibition test. Briefly, birds were vaccinated for NDV on day 1st, followed by 7th and 17th day via drinking water. Samples of blood were taken through slaughtering on the day after the 35th to determine antibody titer. Three $\mathrm{ml}$ blood sample was taken in a non-heparinized vacutainer and placed on a cold chain. After thawing and centrifugation of the sample at 3000 RPM for 15 minutes at $23^{\circ} \mathrm{C}$, serum was separated and kept at $-20^{\circ} \mathrm{C}$ for storage and further procedure. The NDV antibody titer was determined through a commercial HI-based kit as described by (Aksu \& Bozkurt, 2009). For bacterial count, three birds were chosen randomly from each replicate at the experimental period's termination, and slaughtering was performed. After slaughtering, part of the intestine from the duodenal distal end to the ileocaecal junction was severed and taken out. Digesta was taken out from the intestine of about one gram amount and diluted with $0.9 \%$ sodium chloride solution. Dilution was made up to tenfold, and a $1 \mathrm{ml}$ diluted solution from each dilution was taken and inoculated on an agar plate with the help of the spread plate method and the count was done according to the standard procedure (Hartemink \& Rombouts 1999; Hassan et al., 2010); after that, the bacterial population was taken as log10 CFU/gram. The data analysis was performed with the help of one-way ANOVA (Analysis of variance) using the SPSS version 23.0. The difference of means among the treatments was measured through Duncan's comparison test. The significance level was set at $p \leq 0.05$.

\section{RESULTS}

According to this study, non-significant results were noticed in case of feed intake in broilers. However, in 2nd-week feed intake manifested a remarkable difference among different groups (Table 3). Essential oils and organic acids increased the weight of broilers

Table 3 - Effect of essential oil and organic acid on mean daily feed intake ( $\mathrm{g}$ ) of broilers.

\begin{tabular}{l|c|c|c|c|c}
\hline Group & $1^{\text {st }}$ week & $2^{\text {nd }}$ week & $3^{\text {rd }}$ week & $4^{\text {th }}$ week \\
\hline A & $171.60 \pm 8.41$ & $542.27^{\mathrm{a}} \pm 3.20$ & $1183.47 \pm 4.46$ & $2158.93 \pm 6.19$ \\
\hline B & $172.20 \pm 3.51$ & $555.60^{\text {ab }} \pm 2.99$ & $1193.67 \pm 4.28$ & $2156.87 \pm 6.82$ \\
\hline C & $169.67 \pm 0.55$ & $559.27^{\mathrm{b}} \pm 4.65$ & $1195.13 \pm 8.04$ & $2146.20 \pm 9.64$ \\
\hline D & $168.13 \pm 2.05$ & $540.33^{\mathrm{a}} \pm 7.44$ & $1190.07 \pm 10.85$ & $2153.53 \pm 17.25$ & $3298.40 \pm 8.75$ \\
\hline E & $178.20 \pm 7.02$ & $560.07^{\mathrm{b}} \pm 6.14$ & $1190.20 \pm 8.37$ & $2164.20 \pm 15.79$ \\
\hline P-Value & 0.71 & 0.025 & 0.84 & $330.85 \pm 14.34$ & 0.87 \\
\hline
\end{tabular}

*Within a column, values with different superscripts differ statistically at $\mathrm{P}<0.05$ while the standard error of a particular group was written after \pm with mean value. A: Basal diet supplemented with antibiotics; B: EO $0.1 \mathrm{gram} / \mathrm{kg}$ in basal diet; C: OA $1 \mathrm{gram} / \mathrm{kg}$ in basal diet; D: EO $0.1 \mathrm{gram} / \mathrm{kg}$ in basal diet and OA $1 \mathrm{gram} / \mathrm{kg}$ in basal diet; E: Only basal diet (negative control).

significantly except at the 4th weeks of age. The maximum weight was measured in group $B$ having essential oils followed by group $C$ having organic acids. However, the organic acids treated group manifested the highest weight in the first week, followed by an essential oil group. In the 4th week, no significant improvement was noticed, irrespective of the treatment group (Table 4).

Table 4 - Effect of essential oil and organic acid on weekly body weight gain (g) of broilers.

\begin{tabular}{l|c|c|c|c|c|c}
\hline Group & Week 0 & $1^{\text {st }}$ Week & $2^{\text {nd }}$ Week & $3^{\text {rd }}$ Week & $4^{\text {th }}$ Week & $5^{\text {th } W e e k}$ \\
\hline A & $42.00 \pm 0.59$ & $177.52^{\mathrm{a}} \pm 1.94$ & $446.79^{\mathrm{a}} \pm 6.13$ & $816.51^{\mathrm{ab}} \pm 15.82$ & $1407.75 \pm 21.29$ & $2096.26^{\mathrm{a}} \pm 27.51$ \\
\hline B & $42.16 \pm 0.43$ & $191.00^{\mathrm{b}} \pm 3.18$ & $475.57^{\mathrm{c}} \pm 2.70$ & $872.84^{\mathrm{c}} \pm 9.83$ & $1461.86 \pm 14.32$ & $2205.77^{\mathrm{b}} \pm 23.42$ \\
\hline $\mathrm{C}$ & $41.67 \pm 0.55$ & $192.60^{\mathrm{c}} \pm 2.62$ & $472.90^{\mathrm{c}} \pm 5.03$ & $849.66^{\mathrm{bc}} \pm 10.30$ & $1405.07 \pm 17.79$ & $2133.19^{\mathrm{ab}} \pm 23.11$ \\
\hline $\mathrm{D}$ & $41.83 \pm 0.52$ & $186.42^{\mathrm{bc}} \pm 2.66$ & $466.18^{\mathrm{bc}} \pm 1.92$ & $831.44^{\mathrm{b}} \pm 13.60$ & $1419.93 \pm 29.85$ & $2136.05^{\mathrm{a}} \pm 40.62$ \\
\hline E & $42.50 \pm 0.43$ & $182.92^{\mathrm{ab}} \pm 2.90$ & $457.83^{\mathrm{ab}} \pm 4.62$ & $791.32^{\mathrm{a}} \pm 12.88$ & $1400.46 \pm 21.63$ & $2062.97^{\mathrm{a}} \pm 23.89$ \\
\hline P-Value & 0.808 & 0.004 & 0.001 & 0.002 & 0.283 & 0.02 \\
\hline
\end{tabular}

Within a column, values with different superscripts differ statistically at $P<0.05$ while the standard error of a particular group was written after \pm with mean value. A: Basal diet supplemented with antibiotics; B: EO 0.1 gram $/ \mathrm{kg}$ in basal diet; C: OA $1 \mathrm{gram} / \mathrm{kg}$ in basal diet; D: EO 0.1 gram/kg in basal diet and OA $1 \mathrm{gram} / \mathrm{kg}$ in basal diet; E: Only basal diet (negative control).

The feed conversion ratio showed significant improvement in essential oil and organic acid groups compared with the antibiotic group. The most significant improvement was found in essential oil group B while the 4th week had no statistically significant results among all groups. After essential oil, the best improved FCR was noticed in group C (organic acids) at 2 nd and 3rd week. (Table 5).

Our study results exhibited a marked $(p<0.05)$ increase in carcass characteristics, especially in 
Table 5 - Effect of essential oil and organic acid on feed conversion ratio in broilers.

\begin{tabular}{l|c|c|c|c|c}
\hline Groups & Week 1 & Week 2 & Week 3 & Week 4 & Week 5 \\
\hline $\mathrm{A}$ & $0.97^{\mathrm{b}} \pm 0.04$ & $1.22^{\mathrm{bc}} \pm 0.02$ & $1.45^{\mathrm{bc}} \pm 0.03$ & $1.54 \pm 0.03$ & $1.59^{\mathrm{bc}} \pm 0.02$ \\
\hline $\mathrm{B}$ & $0.90^{\mathrm{ab}} \pm 0.01$ & $1.17^{\mathrm{a}} \pm 0.01$ & $1.37^{\mathrm{a}} \pm 0.02$ & $1.48 \pm 0.01$ & $1.50^{\mathrm{a}} \pm 0.02$ \\
\hline $\mathrm{C}$ & $0.88^{\mathrm{a}} \pm 0.01$ & $1.18^{\mathrm{ab}} \pm 0.01$ & $1.41^{\mathrm{ab}} \pm 0.01$ & $1.53 \pm 0.02$ & $1.55^{\mathrm{abc}} \pm 0.01$ \\
\hline $\mathrm{D}$ & $0.90^{\mathrm{ab}} \pm 0.01$ & $1.16^{\mathrm{a}} \pm 0.01$ & $1.43^{\mathrm{ab}} \pm 0.02$ & $1.52 \pm 0.02$ & $1.54^{\mathrm{ab}} \pm 0.02$ \\
\hline $\mathrm{E}$ & $0.97^{\mathrm{b}} \pm 0.02$ & $1.22^{\mathrm{c}} \pm 0.01$ & $1.51^{\mathrm{c}} \pm 0.02$ & $1.55 \pm 0.03$ & $1.61^{\mathrm{c}} \pm 0.02$ \\
\hline P-Value & 0.041 & 0.002 & 0.004 & 0.235 & 0.012 \\
\hline
\end{tabular}

Within a column, values with different superscripts differ statistically at $P<0.05$ while the standard error of a particular group was written after \pm with mean value. A: Basal diet supplemented with antibiotics; B: EO 0.1 gram $/ \mathrm{kg}$ in basal diet; C: OA $1 \mathrm{gram} / \mathrm{kg}$ in basal diet; D: EO $0.1 \mathrm{gram} / \mathrm{kg}$ in basal diet and OA $1 \mathrm{gram} / \mathrm{kg}$ in basal diet; E: Only basal diet (negative control).

eviscerated weight and giblet weight. Group B containing essential oils, revealed the highest eviscerated weight and giblet weight than all other groups, followed by group C (organic acids). In dressing percentage or dressed weight, no significant difference was found among the groups (Table 6).

Table 6 - Effect of essential oils and organic acid on carcass characteristics of broiler.

\begin{tabular}{l|c|c|c|c}
\hline Groups & Live weight & Eviscerated weight & Dressed weight & Giblet weight* \\
\hline A & $1975.25 \pm 19.55$ & $1337.38^{\mathrm{a}} \pm 11.31$ & $1265.75 \pm 19.00$ & $108.67^{\mathrm{a}} \pm 3.93$ \\
\hline $\mathrm{B}$ & $1959.38 \pm 11.88$ & $1434.00^{\mathrm{c}} \pm 9.10$ & $1282.54 \pm 10.47$ & $126.67^{\mathrm{b}} \pm 4.26$ \\
\hline $\mathrm{C}$ & $1947.83 \pm 11.28$ & $1383.92^{\mathrm{b}} \pm 11.58$ & $1263.71 \pm 11.55$ & $118.13^{\mathrm{ab}} \pm 3.07$ \\
\hline $\mathrm{D}$ & $1962.75 \pm 28.10$ & $1416.13^{\mathrm{b}} \pm 14.58$ & $1258.00 \pm 20.03$ & $115.17^{\mathrm{a}} \pm 2.65$ \\
\hline E & $1975.79 \pm 23.25$ & $1323.58^{\mathrm{a}} \pm 10.58$ & $1306.71 \pm 20.39$ & $109.25^{\mathrm{a}} \pm 1.89$ \\
\hline P-Value & 0.846 & 0.000 & 0.247 & 0.001 \\
\hline
\end{tabular}

*Giblet weight means the weight of three organs including liver, heart, and Gizzard. Within a column, values with different superscripts differ statistically at $P<0.05$ while the standard error of a particular group was written after \pm with mean value. A: Basal diet supplemented with antibiotics; B: EO 0.1 gram $/ \mathrm{kg}$ in basal diet; C: OA $1 \mathrm{gram} / \mathrm{kg}$ in basal diet; D: EO $0.1 \mathrm{gram} / \mathrm{kg}$ in basal diet and OA $1 \mathrm{gram} / \mathrm{kg}$ in basal diet; E: Only basal diet (negative control).

Our study revealed no remarkable change in total cholesterol and high-density lipoprotein levels when birds were offered essential oil and organic acids in the diet. Low-density lipoprotein was decreased by feeding essential oils and organic acids. Group B containing essential oil has the lowest LDL level as compared to other groups, followed by group C and D (Table 9). Essential oil and organic acids raised the blood glucose level significantly compared to the control group. Glucose level was highest in the organic acid group C followed by group B having essential oil (Table 9). There was no significant effect on antibody titer noticed on the 35th days of age (Table 7).

Table 7 - Effect of essential oil and organic acid on serological parameters of broilers.

\begin{tabular}{l|c|c|c|c|c}
\hline Groups & Cholesterol & LDL & HDL & Glucose & ${\text { Antibody titer } 35^{\text {th }} \text { day }}$ \\
\hline A & $60.83 \pm 7.25$ & $41.00^{\mathrm{b}} \pm 2.37$ & $53.67 \pm 3.37$ & $215.00^{\mathrm{a}} \pm 11.96$ & $4.50 \pm 1.02$ \\
\hline B & $58.17 \pm 5.36$ & $33.50^{\mathrm{a}} \pm 1.61$ & $50.83 \pm 3.36$ & $244.83^{\mathrm{b}} \pm 8.24$ & $6.17 \pm 0.90$ \\
\hline $\mathrm{C}$ & $61.67 \pm 3.55$ & $38.50^{\mathrm{ab}} \pm 1.23$ & $51.83 \pm 2.33$ & $249.67^{\mathrm{b}} \pm 3.78$ & $4.83 \pm 0.48$ \\
\hline $\mathrm{D}$ & $48.83 \pm 4.56$ & $38.83^{\mathrm{ab}} \pm 2.06$ & $44.33 \pm 3.58$ & $233.33^{\mathrm{ab}} \pm 11.67$ & $5.33 \pm 0.95$ \\
\hline E & $46.17 \pm 4.04$ & $41.67^{\mathrm{b}} \pm 1.54$ & $47.17 \pm 1.80$ & $224.50^{\mathrm{ab} \pm 3.18}$ & $4.50 \pm 0.85$ \\
\hline P-Value & 0.133 & 0.031 & 0.204 & 0.051 & 0.624 \\
\hline
\end{tabular}

Within a column, values with different superscripts differ statistically at $P<0.05$ while the standard error of a particular group was written after \pm with mean value. A: Basal diet supplemented with antibiotics; B: EO $0.1 \mathrm{gram} / \mathrm{kg}$ in basal diet; C: OA $1 \mathrm{gram} / \mathrm{kg}$ in basal diet; D: EO $0.1 \mathrm{gram} / \mathrm{kg}$ in basal diet and OA 1 gram $/ \mathrm{kg}$ in basal diet; E: Only basal diet (negative control).

A significant increase in jejunal villus height was observed by feeding essential oil and organic acids to the broilers. The maximum height was noticed in group $C$ having organic acids followed by group B. In the case of villus width and crypts depth, and there was no remarkable difference among the groups (Table 8).
This study revealed that essential oil and organic acids significantly lower the total viable count in broilers' intestine. Our results are showing that the lowest number of aerobic bacteria was counted in group D having both essential oil and organic acid, followed by group $C$ that contains organic acids in the diet (Table 9). 
Table 8 - Effect of essential oil and organic acids on gut health of broilers.

\begin{tabular}{l|c|c|c}
\hline Groups & Villi length & Villi width & Crypts depth \\
\hline A & $714.52^{\mathrm{a}} \pm 1.50$ & $85.69 \pm 4.23$ & $85.31 \pm 14.98$ \\
\hline B & $864.30^{\mathrm{bc}} \pm 30.13$ & $94.35 \pm 1.46$ & $112.20 \pm 12.67$ \\
\hline C & $917.20^{\mathrm{c}} \pm 30.57$ & $92.71 \pm 16.24$ & $93.10 \pm 10.44$ \\
\hline D & $827.53^{\mathrm{b}} \pm 44.22$ & $103.12 \pm 14.01$ & $118.47 \pm 3.42$ \\
\hline E & $756.03^{\mathrm{ab}} \pm 44.49$ & $89.86 \pm 10.46$ & $92.87 \pm 15.63$ \\
\hline P-Value & 0.011 & 0.835 & 0.321 \\
\hline
\end{tabular}

Within a column, values with different superscripts differ statistically at $P<0.05$ while the standard error of a particular group was written after \pm with mean value. A: Basal diet supplemented with antibiotics; B: EO 0.1 gram $/ \mathrm{kg}$ in basal diet; C: OA $1 \mathrm{gram} / \mathrm{kg}$ in basal diet; D: EO $0.1 \mathrm{gram} / \mathrm{kg}$ in basal diet and OA $1 \mathrm{gram} / \mathrm{kg}$ in basal diet; E: Only basal diet (negative control).

Table 9 - Effect of essential oil and organic acids on total bacterial count in broilers.

\begin{tabular}{l|c}
\hline Groups & TBC $(\log 10 \mathrm{cfu} / \mathrm{g})$ \\
\hline A & $8.07 \mathrm{c} \pm 0.06$ \\
\hline B & $7.97 \mathrm{c} \pm 0.01$ \\
\hline C & $7.85 \mathrm{~b} \pm 0.03$ \\
\hline D & $7.65 \mathrm{a} \pm 0.03$ \\
\hline E & $8.48 \mathrm{~d} \pm 0.03$ \\
\hline P-Value & 0.000 \\
\hline
\end{tabular}

Within a column, values with different superscripts differ statistically at $P<0.05$ while the standard error of a particular group was written after \pm with mean value. A: Basal diet supplemented with antibiotics; B: EO $0.1 \mathrm{gram} / \mathrm{kg}$ in basal diet; C: OA $1 \mathrm{gram} /$ $\mathrm{kg}$ in basal diet; D: EO $0.1 \mathrm{gram} / \mathrm{kg}$ in basal diet and OA $1 \mathrm{gram} / \mathrm{kg}$ in basal diet; E: Only basal diet (negative control).

\section{DISCUSSION}

According to this study, non-significant results were noticed in feed intake in broilers except for 2 nd-week. Our study results follow earlier research, which revealed no noticeable influence on weekly feed consumption among organic acid, essential oils, and antibiotics supplemented group (Bozkurt et al., 2012; Cabuk etal., 2014; Mohammadi Gheisar et al., 2015; BasmacioğluMalayoğlu et al., 2016). Essential oils and organic acids increased the weight of broilers significantly except for 4th week than that of the antibiotic group. Several previous studies favor our results, showing the increased body weight by feeding essential oils and organic acid groups rather than a control group containing antibiotics (Basmacioğlu-Malayoğlu et al., 2016; Fathi et al., 2016; Peng et al., 2016; Elnaggar \& EL-Maaty 2017). The feed conversion ratio manifested the significant improvement in essential oil and organic acid groups compared with the antibiotics group. Our results also match with previous studies which show that essential oils, as well as organic acids, have improved FCR in comparison with the control group (Fascina et al., 2012; Basmacioğlu-Malayoğlu et al., 2016), while some studies are against us showing no improvement in growth performance with essential oils as well as organic acids (Belenli et al., 2015; Pathak et al., 2017).
Stimulation of digestion, modulation of gut flora, and increased release of different endogenous digestive enzymes due to essential oils are the possible reasons for improved performance (Popović et al., 2016). Along with the antibacterial effect, herbal extract's antioxidant property may also be the possible reason for enhanced broiler's performance (El-Shenway \& Ali, 2016). In the case of growth performance, essential oils manifested controversy in several previous studies on broilers. Some studies are in favor, while others are against us. It is difficult enough to resolve these controversies and to generate biologically consistent results due to a lot of variations in inclusion levels, active ingredient concentrations, types of essential oil used, surrounding environment conditions, basal feed composition, infectious diseases outbreak, and origin of that herbal extract (Bozkurt et al., 2012; Basmacioğlu-Malayoğlu et al., 2016). Additionally, enhanced broilers' weight and improved FCR may be due to the beneficial impact of organic acids on gut microflora and the bactericidal effect of organic acids because organic acids cause the interference of bacterial cell membrane and macromolecules of cells leading to hindrance in energy metabolism and nutrients transport (Elnaggar \& EL-Maaty, 2017).

Our study results exhibited a marked $(p<0.05)$ increase in carcass characteristics, especially in eviscerated weight and giblet weight. This is also favored by Rehman et al. (2016), who found insignificant results in dressing percentage. Previous studies are also in favor of us, showing that essential oils and organic acids exert better overall carcass traits (Khattak et al., 2013; Peng et al., 2016; Ragaa et al., 2016). While some researches are against our findings, no significant effect on carcass parameters was noticed (El-Shenway \& Ali, 2016; Özsoy et al., 2017; Gomathi et al., 2018). This conflict of results may be due to variation in diet composition and breeds of broilers (Peng et al., 2016). The improvement in carcass characteristics is due to the existence of antioxidants and phenolic compounds in essential oil, decreasing 
the harmful microbial population in the digestive tract of birds and increasing the absorbed amino acid level. Moreover, an active ingredient of essential oil like carvacrol has triggering action on secretions of the pancreas. This high digestive secretion can improve digestion and absorption of certain nutrients (amino acids), leading to improved carcass characteristics (Ragaa et al., 2016). Better digestion and slower transit rate through the intestine due to organic acid feeding make certain improvements in the absorption of specific nutrients leading to better carcass parameters. Moreover, better proteolysis and digestion of proteins and amino acids cause better musculature. This may be the other reason for improved carcass parameters by organic acids (Hossain \& Nargis, 2016).

Our study revealed no remarkable change in total cholesterol and high-density lipoprotein levels due to feeding essential oil and organic acids in the diet. Lowdensity lipoprotein was decreased by feeding essential oils and organic acids. Our results are according to previous research in which essential oil and organic acids decreased the serum LDL concentration. At the same time, HDL remained unchanged (Elnaggar \& El-Tahawy, 2018; Yildirim et al., 2018), and the total cholesterol level also remained unchanged (Popović et al., 2016; Vinus et al., 2017). The reduction in lowdensity cholesterol is the inhibition of specific enzymes like peroxidase and dehydrogenase by herbal extracts (essential oils). Moreover, active ingredients of these essential oils like carvacrol and thymol have a limiting effect on lethal metabolites, resulting in increased blood cholesterol levels (Hedayati \& Manafi, 2018).

Essential oil and organic acids raised the blood glucose level significantly compared to the control group. Our findings match several past studies showing that essential oil and organic acid increased glucose levels compared with the control group (Rahman et al., 2015; Elnaggar \& EL-Maaty, 2017; Elnaggar \&El-Tahawy, 2018). However, some studies are against our findings showing no noticeable influence on broilers' glucose level (Belenli et al., 2015). There was no significant effect on antibody titer noticed at 35th days of age (Table 9). Our results match previous studies with no significant influence of dietary essential oils and organic acids separately or in combination with antibody titer at the end of the trial (Fascina et al., 2017).

A significant increase in jejunal villus height was observed by feeding essential oil and organic acids to the broilers. Several previous studies' results are similar to our results showing improvement in villus height, i.e. (Liu et al., 2017; Sukandhiya et al., 2017). If villus length and crypt depth are shorter, the bird has a lower nutrient absorption rate due to less surface area available for absorption, and enterocytes are less mature. Thus less nutrient absorption leads to the poor performance of the bird (Paiva et al., 2014). Moreover, essential oils and organic acids cause regulation and balancing effect on gastrointestinal microflora. This effect may be beneficial in improving gut morphology (Zeng et al., 2015). Furthermore, improved intestinal morphology may be due to the anti-inflammatory and anti-oxidation mechanism of essential oils and organic acids (Du et al., 2016; Gao et al., 2019).

This study revealed that essential oil and organic acids have a significant lowering effect on the total viable count in broilers' intestine. Our results are showing that the lowest number of aerobic bacteria was counted in the group " $D$," which contains both essential oil and organic acid, followed by group " $C$ " that contains organic acids in the basal diet. Our results are matching with previous researches, which exhibited that essential oil and organic acids have a significant decreasing effect on bacterial gut count (Basmacioğlu-Malayoğlu et al., 2016; Ndelekwute et al., 2018) and Chowdhury et al. (2018) also observed that pathogenic bacterial count like Escherichia coli was reduced by feeding cinnamon essential oil, but beneficial bacterial species like Lactobacillus spp. was unaffected. However, Pathak et al. (2016) observed no noticeable effect on a total viable bacterial count by feeding cinnamaldehyde and formic acid to the broilers. The lipophilic nature of organic acids in their un-dissociated form causes them to enter the bacterial cell through passive diffusion. This intracellular acid affects cells' normal physiology because the bacterial cell cannot bear acidic $\mathrm{pH}$, causing the stoppage of microbial enzymes and transport systems, leading to inhibition of bacterial growth (Ragaa \& Korany, 2016). This may be the reason behind the antibacterial activity of organic acids.

\section{CONCLUSION}

Hence, we concluded that essential oil and organic acids have improved performance, carcass parameters, serum biochemistry, gut health, and decreased bacterial count. The consequences of group B (Essential oil supplemented) were the best among all treatment groups. According to our research, almost no synergism between essential oil and organic acids was noticed except for the gut microbial count parameter. So essential oil or organic acids can be a better substitute for antibiotics separately rather than in combination. 


\section{Effect of Essential Oil and Organic Acid on Performance, Gut Health, Bacterial Count and Serological Parameters in Broiler}

\section{CONFLICT OF INTERESTS STATEMENT}

The authors declare that there is no conflict of interest regarding this article's publication.

\section{FINANCIAL DISCLOSURE STATEMENT}

There was financial support for this research.

\section{ANIMAL RIGHTS STATEMENT}

The experiments on animals were conducted following the local Ethical Committee laws and regulations regarding the care and use of experimental animals.

\section{REFERENCES}

Abudabos AM, Alyemni AH, Dafalla YM, Khan RU. Effect of organic acid blend and Bacillus subtilis alone or in combination on growth traits, blood biochemical and antioxidant status in broilers exposed to Salmonella typhimurium challenge during the starter phase. Journal of Applied Animal Research 2017;45(1):538-542.

Adil S, Banday T, Bhat GA, Mir MS, Rehman M. Effect of dietary supplementation of organic acids on performance, intestinal histomorphology, and serum biochemistry of broiler chicken. Veterinary Medicine International 2010;2010:479485.

Agyare C, Boamah VE, Zumbi CN, Osei FB. Antibiotic use in poultry production and its effects on bacterial resistance. In: Agyare C, Boamah VE, Zumbi CN, Osei FB. Antimicrobial resistance - a global threat 2018. Available from: https://www.intechopen.com/books/ antimicrobial-resistance-a-global-threat/antibiotic-use-in-poultryproduction-and-its-effects-on-bacterial-resistance

Aksu T, Bozkurt AS. Effect of dietary essential oils and/or humic acids on broiler performance, microbial population of intestinal content and antibody titres in the summer season. Kafkas Üniversitesi Veteriner Fakültesi Dergisi 2009;15:185-190.

Basmacioğlu-Malayoğlu H, Ozdemir P, Bağriyanik H. Influence of an organic acid blend and essential oil blend, individually or in combination, on growth performance, carcass parameters, apparent digestibility, intestinal microflora and intestinal morphology of broilers. British Poultry Science 2016;57:227-234.

Belenli D, Udum D, Cengiz SŞ, Polat Ü. Influence of various volatile oils as a dietary supplement on biochemical and performance parameters in broilers. Journal of Environmental Sciences 2015;9:47-55.

Bozkurt M, Küçükyılmaz K, Çatlı A, Çınar M, Çabuk M, Alçiçek A. Effects of administering an essential oil mixture and an organic acid blend separately and combined to diets on broiler performance. Archiv fur Geflugelkunde 2012;76(2):81-87.

Cabuk M, Eratak S, Alçiçek A, Tuglu I. Effect of herbal essential oil mixture on intestinal mucosal development, growth performance, and weights of internal organs of quails. Journal of Essential Oil Bearing Plants 2014;17(4):599-606

Chand N, Naz S, Shah Z, Khan S, Shah A, Khan RU. Growth performance and immune status of broilers fed graded levels of Albizia lebbeck seeds. Pakistan Journal of Zoology 2014;46:574-577.

Chowdhury S, Mandal GP, Patra AK, Kumar P, Samanta I, Pradhan S, Samanta AK. Different essential oils in diets of broiler chickens: 2.
Gut microbes and morphology, immune response, and some blood profile and antioxidant enzymes. Animal Feed Science and Technology 2018;236:39-47.

Du E, Wang W, Gan L, Li Z, Guo S, Guo Y. Effects of thymol and carvacrol supplementation on intestinal integrity and immune responses of broiler chickens challenged with Clostridium perfringens. Journal of Animal Science and Biotechnology 2016;7:19.

El-Shenway AM, Ali Gl. Effect of Some Organic Acids and Essential Oils as Feed Additives on Growth Performance, Immune Response and Carcass Quality of Japanese Quail. Alexandria Journal for Veterinary Sciences 2016;51(1): 68-77.

Elnaggar AS, EL-Maaty HMA. Impact of using organic acids on growth performance, blood biochemical and hematological traits and immune response of ducks (Cairina moschata). Egyptian Poultry Science Journal 2017;37(3):907-925.

Elnaggar AS, El-Tahawy W. Productive performance, physiological and immunological response of broiler chicks as affected by dietary aromatic plants and their essential oils. Egyptian Poultry Science Journal 2018;38(3)

Fascina VB, Pasquali G, Carvalho F, Muro E, Vercese F, Aoyagi M, et al., Effects of phytogenic additives and organic acids, alone or in combination, on the performance, intestinal quality and immune responses of broiler chickens. Brazilian Journal of Poultry Science 2017;19(3):497-508.

Fascina VB, Sartori JR, Gonzales E, Carvalho FBd, Souza IMGPd, Polycarpo GdV, et al., Phytogenic additives and organic acids in broiler chicken diets. Revista Brasileira de Zootecnia 2012;41(10):2189-2197.

Fathi R, Samadi MS, Qotbi A, Seidavi A, Martínez-Marín AL. Effects of feed supplementation with increasing levels of organic acids on growth performance, carcass traits, gut microbiota and $\mathrm{pH}$, plasma metabolites, and immune response of broilers. Animal Science Papers Reports 2016;34(2);195-206

Gao Y-Y, Zhang X-L, Xu L-H, Peng H, Wang C-K, Bi Y-Z. Encapsulated blends of essential oils and organic acids improved performance, intestinal morphology, cecal microflora, and jejunal enzyme activity of broilers. Czech Journal of Animal Science 2019;64(5):189-198

Gomathi G, Senthilkumar S, Natarajan A, Amutha R, Purushothaman MR. Effect of dietary supplementation of cinnamon oil and sodium butyrate on carcass characteristics and meat quality of broiler chicken. Veterinary World 2018;11(7):959.

Gopi M, Karthik K, Manjunathachar HV, Tamilmahan P, Kesavan M, Dashprakash $\mathrm{M}$, et al., Essential oils as a feed additive in poultry nutrition. Advances in Animal and Veterinary Sciences 2014;2(1):1-7.

Hassan $H$, Youssef AW, Ali H, Mohamed M. Adding phytogenic material and/or organic acids to broiler diets: Effect on performance, nutrient digestibility and net profit. Asian Journal of Poultry Science 2015;9(2):97-105

Hedayati M, Manafi M. Evaluation of anherbal compound, a commercial probiotic, and an antibiotic growth promoter on the performance, intestinal bacterial population, antibody titers, and morphology of the jejunum and ileum of broilers. Brazilian Journal of Poultry Science 2018;20(2):305-316.

Hossain M, Nargis F. Supplementation of organic acid blends in water improves growth, meat yield, dressing parameters and bone development of broilers. Bangladesh Journal of Animal Science 2016;45(1):7-18.

Hartemink R, Rombouts FM. Comparison of media for the detection of bifidobacteria, lactobacilli and total anaerobes from faecal samples. Journal of Microbiology Methods 1999;36:181-192. 
Iqbal H, Rahman A, Khanum S, Arshad M, Badar IH, Asif AR, Hayat Z, Iqbal MA

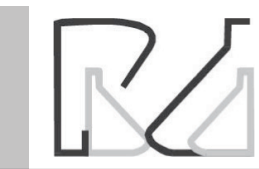

Effect of Essential Oil and Organic Acid on Performance, Gut Health, Bacterial Count and Serological Parameters in Broiler
Hassan $\mathrm{H}$, Mohamed M, Youssef AW, Hassan ER. Effect of using organic acids to substitute antibiotic growth promoters on performance and intestinal microflora of broilers. Asian-Australian Journal of Animal Science 2010;23:1348-1353.

Kamal AM, Ragaa NM. Effect of dietary supplementation of organic acids on performance and serum biochemistry of broiler chicken. Natural Science 2014;12(2):38-45.

Khan SH, Iqbal J. Recent advances in the role of organic acids in poultry nutrition. Journal of applied animal research 2016;44(1):359-369.

Khattak F, Ronchi A, Castelli P, Sparks N. Effects of natural blend of essential oil on growth performance, blood biochemistry, cecal morphology, and carcass quality of broiler chickens. Poultry Science 2013;93(1):132-137.

Kim JW, Kim JH, Kil DY. Dietary organic acids for broiler chickens: a review. Revista Colombiana de Ciencias Pecuaria 2015;28(2):109-123.

Liu Y, Yang $X$, Xin H, Chen S, Yang C, Duan Y, et al., Effects of a protected inclusion of organic acids and essential oils as antibiotic growth promoter alternative on growth performance, intestinal morphology and gut microflora in broilers. Animal Science Journal 2017;88(9):14141424.

Mehdi $Y$, Létourneau-Montminy M-P, Gaucher M-L, Chorfi $Y$, Suresh $G$, Rouissi T, et al., Use of antibiotics in broiler production: Global impacts and alternatives. Animal Nutrition 2018;4(2):170-178.

Mohammadi Gheisar M, Hosseindoust A, Kim I. Evaluating the effect of microencapsulated blends of organic acids and essential oils in broiler chickens diet. Journal of Applied Poultry Research 2015;24(4):511-519.

Ndelekwute EK, Enyenihi GE, Essien EB. Effect of organic acid treated diets fed during finisher phase on gut microbiota and blood profile of broiler chickens. Journal of Dairy \& Veterinary Sciences 2018;5(4).

O'Bryan CA, Pendleton SJ, Crandall PG, Ricke SC. Potential of plant essential oils and their components in animal agriculture-in vitro studies on antibacterial mode of action. Frontiers in Veterinary Science 2015;2(35).

Özsoy B, Ölmez M, Karadağoğlu Ö, Şahin T. Determination of the effect of mixture of essential oil and organic acid containing at different levels on broiler rations on fattening performance, carcass parameters and some internal organ weights. Lalahan Hayvancılık Araștırma Enstitüsü Dergisi 2017; 57(2):77-82.

Paiva D, Walk C, McElroy A. Dietary calcium, phosphorus, and phytase effects on bird performance, intestinal morphology, mineral digestibility, and bone ash during a natural necrotic enteritis episode. Poultry Science 2014; 93(11):2752-2762.

Panda A, Rao S., Raju M., Sunder G.S.: Effect of butyric acid on performance, gastrointestinal tract health and carcass characteristics in broiler chickens. Asian-Australasian Journal of Animal Sciences 2009;22(7):1026-1031.

Pathak M, Mandal G, Patra A, Samanta I, Pradhan S, Haldar S. Effects of dietary supplementation of cinnamaldehyde and formic acid on growth performance, intestinal microbiota and immune response in broiler chickens. Animal Production Science 2017:57(5):821-827.

Pathak M, Mandal G, Patra A, Samanta I, Pradhan S, Haldar S. Effects of dietary supplementation of cinnamaldehyde and formic acid on growth performance, intestinal microbiota and immune response in broiler chickens. Animal Production Science 2016;57(5):821-827.

Peng Q, Li J, Li Z, Duan Z, Wu Y. Effects of dietary supplementation with oregano essential oil on growth performance, carcass traits and jejunal morphology in broiler chickens. Animal Feed Science and Technology 2016;214:148-153.
Popović S, Puvača N, Kostadinović L, Džinić N, Bošnjak J, Vasiljević M, et al., Effects of dietary essential oils on productive performance, blood lipid profile, enzyme activity and immunological response of broiler chickens. European Poultry Science 2016;80:1-12.

Ragaa NM, Korany RM. Studying the effect of formic acid and potassium diformate on performance, immunity and gut health of broiler chickens. Animal Nutrition 2016;2(4):296-302.

Ragaa NM, Korany RM, Mohamed F. Effect of thyme and/or formic acid dietary supplementation on broiler performance and immunity. Agriculture and Agricultural Science Procedia 2016;10:270-279.

Rahman A, Saima, Pasha TN, Akram M, Abbas Y, Ullah S. Supplementation of exogenous enzymes and organic acid in broiler diets. Eurasian Journal of Veterinary Sciences 2015;31(3):163-169.

Rehman ZU, Haq AU, Akram N, Abd El-Hack ME, Saeed M, Rehman SU, et al., Growth performance, intestinal histomorphology, blood hematology and serum metabolites of broilers chickens fed diet supplemented with graded levels of acetic acid. International Journal of Pharmacology 2016;12(8):874-883.

Robinson K, Becker S, Xiao Y, Lyu W, Yang Q, Zhu H, et al., Differential impact of subtherapeutic antibiotics and ionophores on intestinal microbiota of broilers. Microorganisms 2019;7(9):282 .

Sethiya NK. Review on natural growth promoters available for improving gut health of poultry: an alternative to antibiotic growth promoters. Asian Journal of Poultry Science 2016;10:1-29.

Stefanello C, Rosa DP, Dalmoro YK, Segatto AL, Vieira MS, Moraes ML, et al., Protected blend of organic acids and essential oils improves growth performance, nutrient digestibility, and intestinal health of broiler chickens undergoing an intestinal challenge. Frontiers in Veterinary Science 2020;6:491.

Sukandhiya K, Mani K, Rajendran K, Sangli Vikram Kumar K, Prabhakaran $\mathrm{U}$, Sasidhar T. Influence of dietary supplementation of sodium diformate on the intestinal histo: morphology of broilers in environmentally controlled housing system. International Journal of Chemical Studies 2017;5(6):842-843

Sultan A, Ullah T, Khan S, Khan RU. Effect of organic acid supplementation on the performance and ileal microflora of broiler during finishing period. Pakistan Journal of Zoology 2015;47(3):635-639.

Vinus, Sheoran N, Shunthwal J, Akbar MA, Tewatia BS. Effect of Supplementation of Salts of Organic Acids on Serum and Haematological Parameters of Broilers. International Journal of Current Microbiology and Applied Sciences 2017;6(11):4211-4218.

Wade M, Manwar S, Kuralkar S, Waghmare S, Ingle V, Hajare S. Effect of thyme essential oil on performance of broiler chicken. Journal of Entomology and Zoology Studies 2018;6(3):25-28.

Yang $X$, Xin $H$, Yang C, Yang X. Impact of essential oils and organic acids on the growth performance, digestive functions and immunity of broiler chickens. Animal Nutrition 2018;4(44):388-393.

Yildirim BA, Tunc MA, Gül M, Yildirim F, Yıldız A. The effect of Rosemary (Rosmarinus officinalis L.) extract supplemented into broiler diets, on performance and blood parameters. GSC Biological and Pharmaceutical Sciences 2018;2(3):1-9.

Zeng Z, Zhang S, Wang H, Piao X. Essential oil and aromatic plants as feed additives in non-ruminant nutrition: a review. Journal of Animal Science and Biotechnology 2015;6(1):7. 